\title{
Antiarthritic Potential of Calotropis procera Leaf Fractions in FCA-Induced Arthritic Rats: Involvement of Cellular Inflammatory Mediators and Other Biomarkers
}

\author{
Vandana S. Singh ${ }^{1}$, Shashikant C. Dhawale ${ }^{1}$, Faiyaz Shakeel ${ }^{2}$,, Md. Faiyazuddin ${ }^{3,4}$ and Sultan Alshehri ${ }^{2, *}$ (D) \\ 1 School of Pharmacy, S.R.T.M. University, Nanded 431606, Maharashtra, India; \\ vandana27011990@gmail.com (V.S.S.); sashiprathmesh@gmail.com (S.C.D.) \\ 2 Department of Pharmaceutics, College of Pharmacy, King Saud University, P.O. Box 2457, \\ Riyadh 11451, Saudi Arabia; faiyazs@fastmail.fm \\ 3 School of Pharmacy, Alkarim University, Katihar 854106, Bihar, India; md.faiyazuddin@gmail.com \\ $4 \quad$ Nano Drug Delivery ${ }^{\circledR}$, Raleigh-Durham, NC 27705, USA \\ * Correspondence: salshehri1@ksu.edu.sa
}

\section{check for}

updates

Citation: Singh, V.S.; Dhawale, S.C.; Shakeel, F.; Faiyazuddin, M.;

Alshehri, S. Antiarthritic Potential of Calotropis procera Leaf Fractions in FCA-Induced Arthritic Rats: Involvement of Cellular Inflammatory Mediators and Other Biomarkers. Agriculture 2021, 11, 68. https://doi.org/10.3390/ agriculture 11010068

Received: 5 December 2020 Accepted: 12 January 2021 Published: 15 January 2021

Publisher's Note: MDPI stays neutral with regard to jurisdictional clai$\mathrm{ms}$ in published maps and institutional affiliations.

Copyright: () 2021 by the authors. Licensee MDPI, Basel, Switzerland. This article is an open access article distributed under the terms and conditions of the Creative Commons Attribution (CC BY) license (https:// creativecommons.org/licenses/by/ $4.0 /)$.

\begin{abstract}
Calotropis procera (commonly known as Swallow wort) is described in the Ayurvedic literature for the treatment of inflammation and arthritic disorders. Therefore, in the present work, the antiarthritic activity of potential fractions of Swallow wort leaf was evaluated and compared with standards (indomethacin and ibuprofen). This study was designed in Wistar rats for the investigation of antiarthritic activity and acute toxicity of Swallow wort. Arthritis was induced in Wistar rats by injecting $0.1 \mathrm{~mL}$ of Freund's complete adjuvant (FCA) on the 1st and 7th days subcutaneously into the subplantar region of the left hind paw. Evaluation of our experimental findings suggested that antiarthritic activity of methanol fraction of Swallow wort (MFCP) was greater than ethyl acetate fraction of Swallow wort (EAFCP), equal to standard ibuprofen, and slightly lower than standard indomethacin. MFCP significantly reduced paw edema on the 17th, 21st, 24th, and 28th days. It also showed significant effect $(p<0.01)$ on arthritic score, paw withdrawal latency, and body weight. The inhibition of serum lysosomal enzymes and proinflammatory cytokines along with improvement of radiographic features of hind legs was also recorded with MFCP. Finally, it was concluded that MFCP can be a feasible therapeutic candidate for the treatment of inflammatory arthritis.
\end{abstract}

Keywords: Calotropis procera leaves; chronic inflammatory model; cytokines; Freund's complete adjuvant; indomethacin

\section{Introduction}

Rheumatoid arthritis (RA) is a chronic autoimmune disease which is characterized by nonspecific inflammation of peripheral joints, destruction of articular tissues, and deformities in the joints [1,2]. An epidemiology of RA in terms of males to females has been reported as 1:3, and the prevalence was found to be $1 \%$ around the globe [3]. The inflammatory cytokines such as "tumor necrosis factor- $\alpha$ (TNF- $\alpha$ ), interleukin- $1 \beta$ (IL-1 $\beta$ ), and interleukin-6 (IL-6)" are the major biomarkers responsible for the inflammation and joint damage during the development of RA [4-6].

Presently, the treatment strategies focus on the reduction in inflammation in the joints, as no proper treatments are available. Conventional medicines including analgesics, steroids, nonsteroidal anti-inflammatory drugs (NSAIDs), glucocorticoids, diseasemodifying antirheumatic drugs (DMARDs), and anticytokines are reported to show very limited success rates in the treatment of RA, although these medicines are helpful in controlling the symptoms of acute RA [4,7]. Mild to moderate arthritis is relieved by the use of different analgesics. However, these analgesics did not offer anti-inflammatory efficacy and hence these are usually administered in combination with other drugs [8]. Most of the 
NSAIDs are reported to possess both analgesic and anti-inflammatory efficacy but are not capable of preventing the destruction of joints [9]. Ultimately, the treatments with NSAIDs fail to produce long-term benefits and produce serious adverse effects such as gastric toxicity and cardiotoxicity, which limit their application in the treatment of RA [10,11]. Therefore, the search for drugs with low or no adverse effects are of prime importance to treat RA. Herbal drugs constitute a major part of all the traditional systems of medicine. According to the $\mathrm{WHO}, 80 \%$ of the world's population use herbal medicines for primary health care. Herbal medicine is a triumph of popular therapeutic diversity and is also used to derive a number of synthetic medicines such as aspirin, paclitaxel, digoxin, and morphine, etc. $[12,13]$. Several plant-based materials showed potent anti-inflammatory activity in animal models which could also be useful in the treatment of RA $[14,15]$. These plant-based medicines are supposed to have low incidence of serious adverse effects, low cost, and be easily accessible to the consumers $[16,17]$.

Calotropis procera Linn. (commonly known as Swallow wort), which belongs to the Asclepiadaceae family, is an Ayurvedic plant with important medicinal properties [18,19]. It is represented in India by two different species-viz., C. procera and C. gigantean [19,20]. Traditionally, it is used in the treatment of ulcers, leprosy, cancers, piles, and liver diseases [21,22]. It has also been reported to have purgative, anthelmintic, analgesic, anti-inflammatory, protective, anticoagulant, antipyretic, and antimicrobial activities $[18,19,22,23]$. C. procera (Swallow wort) latex has been used as a hepatoprotective [21], anti-inflammatory [24], anthelmintic [25], anticonvulsant [26], and antimicrobial agent [27].

A traditional claim made about Swallow wort includes its beneficial effects in inflammation and arthritis. Anti-inflammatory activity of the latex of this plant has been demonstrated in various animal models [28]. The protective effects of different extracts of Swallow wort latex have also been evaluated against inflammation and oxidative stress in monoarthritis induced by different inflammatory mediators [29-34]. Although the leaves of this plant are reported to have traditional uses regarding its beneficial effects in inflammatory conditions, these claims are not experimentally verified. Previous studies have shown the significant anti-inflammatory activity of this plant both in in vitro and in vivo models [24]. Therefore, the current investigations were planned to explore the antiarthritic potential of different fractions of Swallow wort for the evaluation of antiarthritic potential using Freund's complete adjuvant (FCA) model on Wistar rats, because no such study has been carried out in the past.

\section{Materials and Methods}

\subsection{Procurement and Authentication of the Plant}

The leaves of Swallow wort were procured from the herbal garden of Swami Ramanand Teerth Marathwada University, Nanded, in the month of January 2017. The Swallow wort plant specimens were identified and authenticated at Botanical Survey of India, Pune, India, where a voucher specimen is preserved (BSI/WC/100-1/Tech./2017/1). The fresh leaves were washed properly with tap water and shade dried for one week. The dried leaves were ground coarsely using an electrical mixer and stored in airtight plastic bags in a cool and dark place until further use.

\subsection{Materials}

FCA was procured from "Sigma Aldrich (Bangalore, India)". Indomethacin and ibuprofen were received as gift samples kindly provided by "Wockhardt Research Center (Aurangabad, India)". Petroleum ether, chloroform, ethyl acetate, acetone, ethanol, and methanol were procured from "S.D. Fine Chemicals (Mumbai, India)". All the reagents used were of analytical grade. 


\subsection{Plant Extraction and Characterization}

\subsubsection{Extraction Method}

The successive extraction of dried powder of Swallow wort leaves was carried out using Soxhlet extractor. The solvents used to obtain different fractions of Swallow wort leaves were petroleum ether, chloroform, ethyl acetate, acetone, ethanol, and methanol. The fractions were concentrated by evaporating their respective solvents under reduced pressure using rotary vacuum evaporator at $42-45^{\circ} \mathrm{C}$. The obtained fractions were further dried at room temperature in a petri dish and stored in refrigerator at $4-6{ }^{\circ} \mathrm{C}$ till further evaluation.

\subsubsection{Qualitative Phytochemical Screening}

The bioactive agents present in Swallow wort were detected by a standard phytochemical screening procedure and inference was based on visual observations of color change or precipitate formation [35]. The stock solution of the plant extracts was prepared with their respective solvents. Mayer's reagent (potassium mercuric iodide solution) was added to $1 \mathrm{~mL}$ of plant fraction, and the appearance of a cream precipitate was indicated as the end point for the presence of alkaloids. In total, $1 \mathrm{~mL}$ of glacial acetic acid was added to $1 \mathrm{~mL}$ of plant fraction, which was dissolved and then cooled, followed by addition of 2-3 drops of ferric chloride. Then, $2 \mathrm{~mL}$ of conc. $\mathrm{H}_{2} \mathrm{SO}_{4}$ was carefully added along the walls of test tube; the appearance of reddish brown ring at the junction of two layers indicated the presence of glycosides. Steroids were investigated by adding $5 \mathrm{~mL}$ of chloroform and a few drops of conc. $\mathrm{H}_{2} \mathrm{SO}_{4}$; this mixture was allowed to stand for some time, the reddish precipitate in the lower layer indicates the presence of steroids. The formation of foam upon vigorous shaking of plant fraction solution indicates the presence of saponins. Flavonoids were investigated by adding basic lead acetate separately to $1 \mathrm{~mL}$ of plant fraction. A bulky reddish brown precipitate indicates the presence of flavonoids.

\subsection{Biological Evaluation}

\subsubsection{Prediction of Biological Activity}

The prediction of the activity spectra for substance (PASS) is an online software database program used to predict the various biological properties of compounds [36]. PASS software helps estimate the probable biological activity of drugs such as organic compounds (pursuing molecular weights of 50 to $1250 \mathrm{Da}$ ) or phytoconstituents based on structural activity relationship analysis of training set consisting of information on the structures of more than 205,000 organic compounds which exhibit more than 3750 kinds of biological activity [37,38]. The MDL mole file [ $V$ 3000] $\left({ }^{*} \mathrm{~mol}\right)$ structure of desired phytoconstituent drawn with the help of ACD/Labs chemsketch software 2015 release (file version C10E41) was fed in PASS online Way2drug online software. The software gave the $\mathrm{Pa}$ and Pi values (active and inactive) [38]. The probability of experimental biological and pharmacological activities is high if the value of $\mathrm{Pa}$ is greater than 0.7 and less if $\mathrm{Pa}$ value is $0.5<\mathrm{Pa}>0.7[39]$.

\subsubsection{Experimental Animals}

Male Albino Wistar rats (weighing 180-220 g) were purchased from "Wockhardt Research Center (Aurangabad, India)". The animals were housed under standard animal housing facility with temperature $\left(24 \pm 1{ }^{\circ} \mathrm{C}\right)$, relative humidity $(45-50 \%)$, and $12 \mathrm{~h}$ light/dark cycle. The animals were fed with standard pellet chow diet and water ad libitum. All rats were allowed to adopt laboratory conditions before starting experimental studies. The study protocol was approved by the Institutional Animal Ethics Committee (Reg. No. 731/PO/Re/2002/CPCSEA), Approval No. CPCSEA/CBPL/AH-11 under the Committee for "Purpose of Control and Supervision of Experiments on Animals (CPCSEA)". The ethical protocol and guidelines were strictly followed throughout the experimental studies. 


\subsubsection{Acute Toxicity Studies}

The Swallow wort plant fractions were evaluated for acute toxicity as per the organization for economic co-operation and development (OECD) guidelines 425 . The single oral dose of $2000 \mathrm{mg} / \mathrm{kg}$ of plant fraction was administered to overnight fasted rats and observations were continuously recorded for behavioral profiles for $2 \mathrm{~h}$ and for mortality up to $72 \mathrm{~h}$.

\subsubsection{FCA-Induced Arthritis}

For the evaluation of FCA-induced arthritis, the rats were divided into six different groups (each containing six rats) as follows:

Group I-Vehicle control, $1 \% w / v$ suspension of sodium carboxymethyl cellulose (SCMC) was administered orally;

Group II-Arthritic control, $1 \% w / v$ suspension of SCMC was administered orally;

Group III-Arthritic animals treated with oral administration of standard indomethacin at $10 \mathrm{mg} / \mathrm{kg}$ dose;

Group IV-Arthritic animals treated with oral administration of standard ibuprofen at $15 \mathrm{mg} / \mathrm{kg}$ dose;

Group V-Arthritic animals treated with oral administration of methanolic fraction of Swallow wort (MFCP) at a $300 \mathrm{mg} / \mathrm{kg}$ dose;

Group VI-Arthritic animals treated with oral administration of ethyl acetate fraction of Swallow wort (EAFCP) at a $300 \mathrm{mg} / \mathrm{kg}$ dose.

Around $0.1 \mathrm{~mL}$ of FCA was administered subcutaneously into the subplantar region of the left hind paw on 1st and 7th days to all the animals of all groups except vehicle control [40]. Then, $300 \mathrm{mg} / \mathrm{kg}$ of each of MFCP and EAFCP were orally administered once daily from day 12 to day 28 [41]. The standards (indomethacin and ibuprofen) at the dose of 10 and $15 \mathrm{mg} / \mathrm{kg}$, respectively, were also orally administered once daily from day 12 to day 28 for the evaluation of antiarthritic potential of these standards. The antiarthritic activities of each plant fraction of Swallow wort and standards were determined using a "Plethysmometer (Ugo, Basile, Italy)" by the hind paw method on days 1, 4, 7, 10, 12, 14, 17, 21,24 , and 28 [42]. The percentage inhibition value of each fraction of plant was calculated using its standard formula, described previously [14,16].

Arthritic index was obtained using different pharmacological parameters such as hind paw edema, mechanical withdrawal threshold, body weight, and arthritic score. On the 28th day, the rats were anaesthetized using anesthetic ketamine and blood samples were withdrawn from the retro-orbital puncture for the determination of different biochemical parameters. At the end of the experiment, X-rays of the joints of the hind paws of animals were recorded under mild diethyl ether anesthesia for the evaluation of possible bone, cartilage, and other structural degeneration.

\subsubsection{Paw Volume Evaluation}

The left paw volume was measured up to the lateral malleolus by the mercury displacement method just before FCA injection on 1st day and subsequently at various time intervals until the 28th day using a "Plethysmometer (Ugo, Basile, Italy)" [43]. The alterations in the paw volume were considered as the difference between the final and initial paw volumes.

\subsubsection{Visual Arthritis Scoring System}

The visual arthritis scoring systems were used to assess the severity of the arthritis, as described previously [44]. The arthritis score was ranged from 0 to 4 which is graded as follows: $0=$ normal paw; $1=$ mild swelling and erythema; $2=$ swelling and erythema; 3 = severe swelling and erythema; $4=$ gross deformity and inability. 


\subsubsection{Evaluation of Thermal Hyperalgesia}

The thermal hyperalgesia/paw withdrawal latency of injected paw was evaluated using hot plate method just before FCA injections on the 1st day and subsequently at various time intervals until the 28th day. The paw was placed on the flat surface of the hot plate which was maintained at $55 \pm 5^{\circ} \mathrm{C}$. The reaction time to heat stimulus in terms of paw licking or jumping was recorded as the end point of the pain threshold [45]. A cut off time was selected as $20 \mathrm{~s}$ to avoid tissue damage.

\subsubsection{Body Weight Recording}

The body weight was recorded during the experimental period using a Digital Weighing Balance (Sartorius 1413, MP 8/8-1, Bohemia, NY, USA) just before FCA injections on the 1st day and subsequently at various time intervals until the 28th day [46].

\subsubsection{Determination of the Weight of Spleen and Thymus}

At the end of experimental studies, the rats were sacrificed using ketamine anesthesia. Then, the thymuses and spleens of all rats were taken and weights were recorded.

\subsubsection{Biochemical Estimation}

On the 28th day, the blood samples of the rats were withdrawn from the retro-orbital puncture of all the animal groups and various biochemical parameters such as aspartate aminotransferase (AST), alanine transaminase (ALT), and alkaline phosphatase (ALP) were estimated using a standard kit (Sigma-Aldrich assay kit) [47].

\subsubsection{Estimation of Serum Parameters}

Various hematological/serum parameters were estimated using routine laboratory techniques. The levels of serum C-reactive protein (CRP) and rheumatoid factor (RF) were estimated using commercial kits (Aspen laboratories) following the manufacturer's instructions.

\subsubsection{Proinflammatory Biomarkers (TNF- $\alpha$ and IL-6)}

For the estimation of proinflammatory biomarkers such as TNF- $\alpha$ and IL-6, the blood samples were left to stand for about $30 \mathrm{~min}$. The serum was separated from the blood by centrifugation at $3000 \mathrm{rpm}$ for about $10 \mathrm{~min}$. The obtained serum samples were stored at $-20{ }^{\circ} \mathrm{C}$ until further evaluation. Proinflammatory biomarkers (TNF- $\alpha$ and IL-6) were estimated using readymade ELISA reagent kits [40].

\subsubsection{Radiological Analysis of Ankle Joints}

On the 28th day, the animals were anaesthetized using ketamine and radiographs of FCA-injected hind paws were recorded using X-ray (GE DX-300). Radiographic analysis of hind paws was carried out at $40 \mathrm{kV}$ peak and $12 \mathrm{Ms}$. The X-ray image was interpreted for the radiographic changes.

\subsection{Data and Statistical Analysis}

The values are expressed as mean \pm SEM for 6 animals. The experimental results were analyzed statistically using one-way ANOVA followed by Dunnett test using Graphpad instant software. $p<0.05$ was considered a statistically significant value.

\section{Results}

\subsection{Plant Extraction and Characterization}

\subsubsection{Extractive Value of Fraction}

After extracting $702 \mathrm{~g}$ of powder Swallow wort leaves with petroleum ether, chloroform, ethyl acetate, acetone, and methanol, the fraction yields were found to be 12.25 , $12.51,5.87,5.43$, and $42.66 \mathrm{~g}$ of the fraction, respectively. The yield was recorded highest in 
methanol fraction of Swallow wort leaves, while the lowest one was found in acetone fraction. The yield was negligible for ethanol fraction. The yield of above mentioned fractions of Swallow wort leaves was not found in the literature. However, the yield of methanol fraction of Swallow wort latex was recorded as 25\% (dry weight) in the literature [30]. In the present study, the yield of methanol fraction of Swallow wort leaves was $42.66 \mathrm{~g}$ out of $702 \mathrm{~g}$ of powder, which was approximately $6.10 \%$. These observations suggested that latex of Swallow wort is better than its leaves in terms of yield.

\subsubsection{Phytochemical Screening}

The preliminary phytochemical screening of MFCP and EAFCP demonstrated the presence of alkaloids, glycosides, flavonoids, and steroids. Other studied fractions did not show the presence of all these compounds.

\subsection{Biological Evaluation}

\subsubsection{PASS Prediction}

We performed the PASS prediction of various phytoconstituents of Swallow wort leaves for the prediction of various biological activities such as anti-inflammatory and antiarthritic activity. From this study, we found most of the constituents such as $\alpha$-amyrin, $\beta$-amyrin, $\beta$ - sitosterol, and stigmasterol have shown good anti-inflammatory activity (Table 1).

Table 1. Prediction of activity spectra for substance (PASS) of Swallow wort for antiarthritic activity.

\begin{tabular}{|c|c|c|c|}
\hline Phytoconstituent & $\mathbf{P a}$ & $\mathbf{P i}$ & Activity \\
\hline \multirow{3}{*}{$\alpha$-amyrin } & 0.889 & 0.004 & Anti-inflammatory \\
\hline & 0.835 & 0.002 & Nitric oxide antagonist \\
\hline & 0.522 & 0.043 & Antiarthritic \\
\hline \multirow{3}{*}{$\beta$-amyrin } & 0.411 & 0.011 & Antioxidant \\
\hline & 0.843 & 0.005 & Anti-inflammatory \\
\hline & 0.793 & 0.003 & Nitric oxide antagonist \\
\hline \multirow{3}{*}{ Calitropigenin } & 0.405 & 0.012 & Antioxidant \\
\hline & 0.357 & 0.119 & Anti-inflammatory \\
\hline & 0.490 & 0.060 & Anti-inflammatory \\
\hline \multirow{3}{*}{ Asclepin } & 0.357 & 0.119 & Anti-inflammatory \\
\hline & 0.490 & 0.060 & Anti-inflammatory \\
\hline & 0.608 & 0.005 & Calcium regulator \\
\hline \multirow{3}{*}{$\beta$-sitosterol } & 0.572 & 0.038 & Anti-inflammatory \\
\hline & 0.482 & 0.004 & Anti-inflammatory, Ophthalmic \\
\hline & 0.740 & 0.011 & Anti-inflammatory \\
\hline \multirow{3}{*}{ Stigmasterol } & 0.669 & 0.004 & Calcium regulator \\
\hline & 0.662 & 0.006 & Bone diseases treatment \\
\hline & 0.373 & 0.017 & Anti-inflammatory, ophthalmic \\
\hline
\end{tabular}

\subsubsection{FCA-Induced Arthritis}

The subplantar injection of FCA in the left hind paw of rats resulted in the progressive increase in the volume of the ipsilateral (injected) paw as well as contralateral (noninjected) paw. 


\subsubsection{Effect of Swallow Wort Fractions on Paw Volume}

FCA was administered on 1st and 7th days, which resulted in the progressive increase in paw volume. The treatment with standards (indomethacin and ibuprofen) and plant fractions (MFCP and EAFCP) started from the day 12 to day 28. As presented in Table 2, it can be seen that both of the standards as well as fractions caused significant abatement of paw volume which was noticed from day 17 to day 28 . The MFCP demonstrated the same level of antiarthritic effects (46.42\%) with that of ibuprofen, which was slightly lower than that of indomethacin $(51.78 \%)$. However, the antiarthritic effects of EAFCP $(26.78 \%)$ were found to be significantly lower than both of the standards (indomethacin and ibuprofen) and MFCP $(p<0.01)$. Hence, MFCP could be used as an alternative to indomethacin and ibuprofen in the treatment of RA.

Table 2. Effect of Swallow wort fractions on Freund's complete adjuvant (FCA)-induced paw volume of rats.

\begin{tabular}{|c|c|c|c|c|c|c|c|c|c|c|}
\hline \multirow{2}{*}{ Groups } & \multicolumn{9}{|c|}{ Paw Volume on Different Days (mL) } & \multirow{2}{*}{$\begin{array}{c}\text { Inhibition } \\
(\%)\end{array}$} \\
\hline & 4th & 7 th & 10th & 12th & 14th & 17th & 21st & 24th & 28th & \\
\hline Normal & $\begin{array}{c}0.18 \pm \\
0.009\end{array}$ & $\begin{array}{c}0.19 \pm \\
0.012\end{array}$ & $\begin{array}{l}0.2 \pm \\
0.008\end{array}$ & $\begin{array}{c}0.20 \pm \\
0.008\end{array}$ & $\begin{array}{c}0.2 \pm \\
0.08\end{array}$ & $\begin{array}{c}0.19 \pm \\
0.01\end{array}$ & $\begin{array}{c}0.2 \pm \\
0.02\end{array}$ & $\begin{array}{c}0.21 \pm \\
0.01\end{array}$ & $\begin{array}{c}0.21 \pm \\
0.008\end{array}$ & - \\
\hline $\begin{array}{l}\text { Arthritic } \\
\text { control }\end{array}$ & $\begin{array}{l}0.38 \pm \\
0.011^{\#}\end{array}$ & $\begin{array}{l}0.50 \pm \\
0.012^{\#}\end{array}$ & $\begin{array}{l}0.59 \pm \\
0.008^{\#}\end{array}$ & $\begin{array}{c}0.61 \pm \\
0.01\end{array}$ & $\begin{array}{l}0.59 \pm \\
0.008^{\#}\end{array}$ & $\begin{array}{l}0.59 \pm \\
0.008^{\#}\end{array}$ & $\begin{array}{l}0.58 \pm \\
0.005^{\#}\end{array}$ & $\begin{array}{l}0.57 \pm \\
0.005^{\#}\end{array}$ & $\begin{array}{l}0.56 \pm \\
0.004^{\#}\end{array}$ & - \\
\hline Indomethacin & $\begin{array}{c}0.38 \pm \\
0.009\end{array}$ & $\begin{array}{c}0.51 \pm \\
0.012\end{array}$ & $\begin{array}{c}0.59 \pm \\
0.014\end{array}$ & $\begin{array}{c}0.61 \pm \\
0.01\end{array}$ & $\begin{array}{c}0.58 \pm \\
0.004\end{array}$ & $\begin{array}{c}0.42 \pm \\
0.005^{* *}\end{array}$ & $\begin{array}{c}0.38 \pm \\
0.005^{* *}\end{array}$ & $\begin{array}{c}0.34 \pm \\
0.006^{* *}\end{array}$ & $\begin{array}{l}0.27 \pm \\
0.01 * *\end{array}$ & 51.78 \\
\hline Ibuprofen & $\begin{array}{c}0.39 \pm \\
0.011\end{array}$ & $\begin{array}{c}0.51 \pm \\
0.012\end{array}$ & $\begin{array}{c}0.59 \pm \\
0.008\end{array}$ & $\begin{array}{c}0.60 \pm \\
0.012\end{array}$ & $\begin{array}{c}0.58 \pm \\
0.012\end{array}$ & $\begin{array}{l}0.44 \pm \\
0.01^{* *}\end{array}$ & $\begin{array}{c}0.42 \pm \\
0.008^{* *}\end{array}$ & $\begin{array}{c}0.37 \pm \\
0.008^{* *}\end{array}$ & $\begin{array}{c}0.3 \pm \\
0.008^{* *}\end{array}$ & 46.42 \\
\hline MFCP & $\begin{array}{c}0.38 \pm \\
0.019\end{array}$ & $\begin{array}{c}0.51 \pm \\
0.012\end{array}$ & $\begin{array}{c}0.58 \pm \\
0.006\end{array}$ & $\begin{array}{c}0.59 \pm \\
0.012\end{array}$ & $\begin{array}{c}0.58 \pm \\
0.009\end{array}$ & $\begin{array}{c}0.44 \pm \\
0.005^{* *}\end{array}$ & $\begin{array}{c}0.42 \pm \\
0.007 * *\end{array}$ & $\begin{array}{l}0.38 \pm \\
0.01 * *\end{array}$ & $\begin{array}{c}0.30 \pm \\
0.008^{* *}\end{array}$ & 46.42 \\
\hline EAFCP & $\begin{array}{c}0.39 \pm \\
0.009\end{array}$ & $\begin{array}{c}0.51 \pm \\
0.012\end{array}$ & $\begin{array}{c}0.59 \pm \\
0.012\end{array}$ & $\begin{array}{c}0.60 \pm \\
0.011\end{array}$ & $\begin{array}{c}0.59 \pm \\
0.008\end{array}$ & $\begin{array}{c}0.58 \pm \\
0.007\end{array}$ & $\begin{array}{l}0.56 \pm \\
0.008 *\end{array}$ & $\begin{array}{c}0.49 \pm \\
0.007^{* *}\end{array}$ & $\begin{array}{c}0.41 \pm \\
0.008^{* *}\end{array}$ & 26.78 \\
\hline
\end{tabular}

Values are mean \pm SEM for 6 animals. ${ }^{*} p<0.05,{ }^{* *} p<0.01$ vs. control group ${ }^{\#} p<0.01$ when compared to normal control. One-way ANOVA followed by Dunnett test were used. Methanol fraction of Swallow wort (MFCP) showed similar percentages inhibition with that of ibuprofen.

\subsubsection{Arthritic Scoring System}

The effect of the administration of different fractions (MFCP and EAFCP) and standards (indomethacin and ibuprofen) on arthritic score was assessed through visual observation. The different grading systems as described in the experimental section were used to assess the arthritic scores. On the 28th day, the MFCP was found to reduce the arthritic score significantly compared to the control and arthritic control $(p<0.01)$. The effect of MFCP was similar to that of standard ibuprofen (Figure 1). Although EAFCP demonstrated lesser effects than MFCP, a significant reduction in arthritic score was recorded compared to the control and arthritic control $(p<0.01)$. Overall, MFCP was found to be better than EAFCP in reducing the arthritic scores in the rats.

\subsubsection{Measurement of Paw Withdrawal Latency}

The significant increment in the paw withdrawal latency was witnessed on day 21 and day 28 in animals treated with MFCP, EAFCP, and standards (Figure 2). The paw withdrawal latency of MFCP $(2.11 \pm 0.17)$ was found to be similar to that of standard ibuprofen $(2.33 \pm 0.18)$ on the 28th day. However, the paw withdrawal latency of EAFCP $(1.74 \pm 0.09)$ was found to be significantly lower than MFCP and both of the standards (indomethacin and ibuprofen) on the 28th day $(p<0.05)$. These observations indicate the superiority of MFCP over EAFCP in the increment of paw withdrawal latency. 


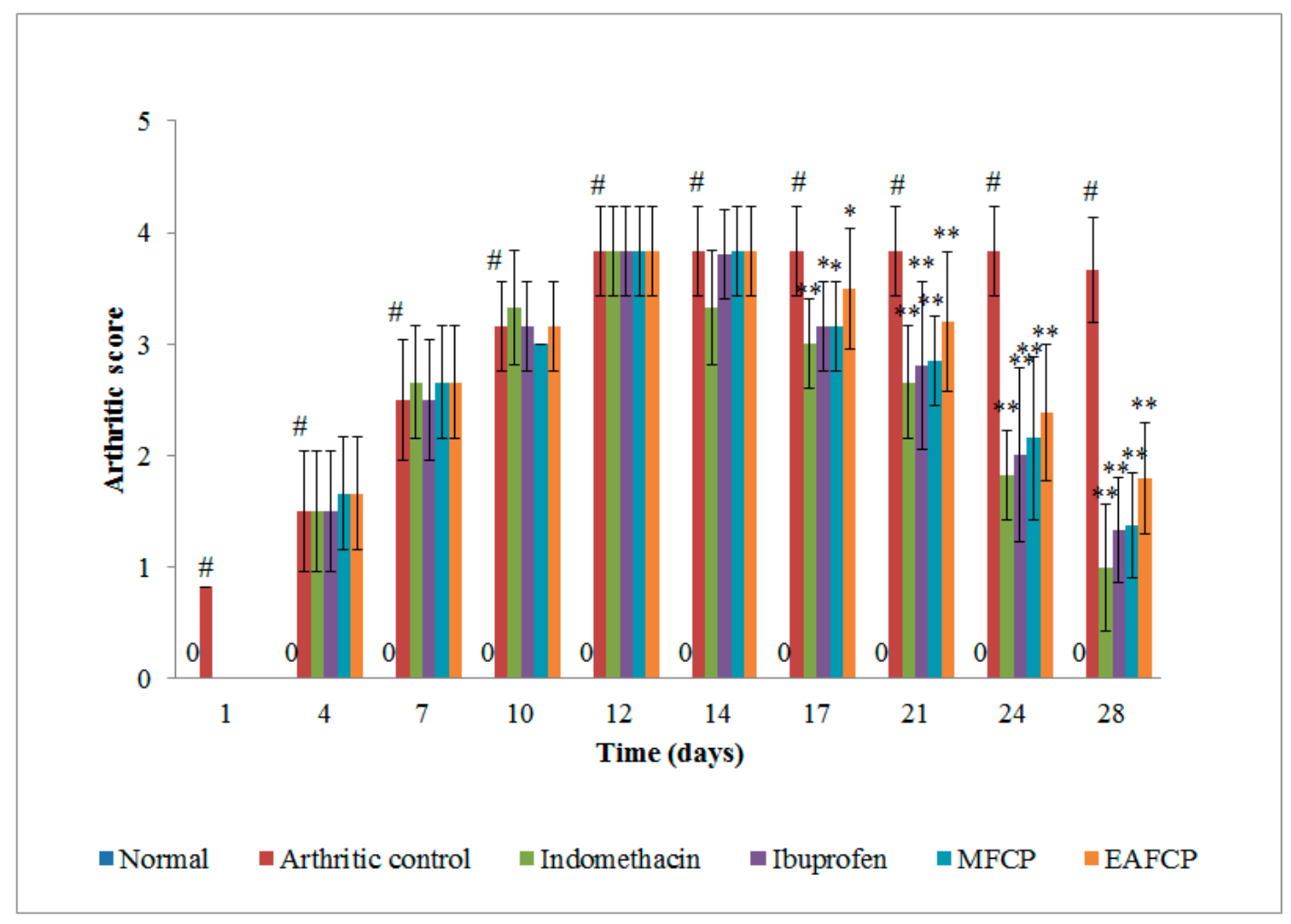

Figure 1. Effect of Swallow wort fractions on arthritic score. Values are mean \pm SEM for 6 animals; statistical analysis by one-way ANOVA followed by Dunnett test using Graphpad Instat software; ${ }^{*} p<0.05,{ }^{* *} p<0.01$ when compared to arthritic control, and ${ }^{\#} p<0.01$ when compared to normal control.

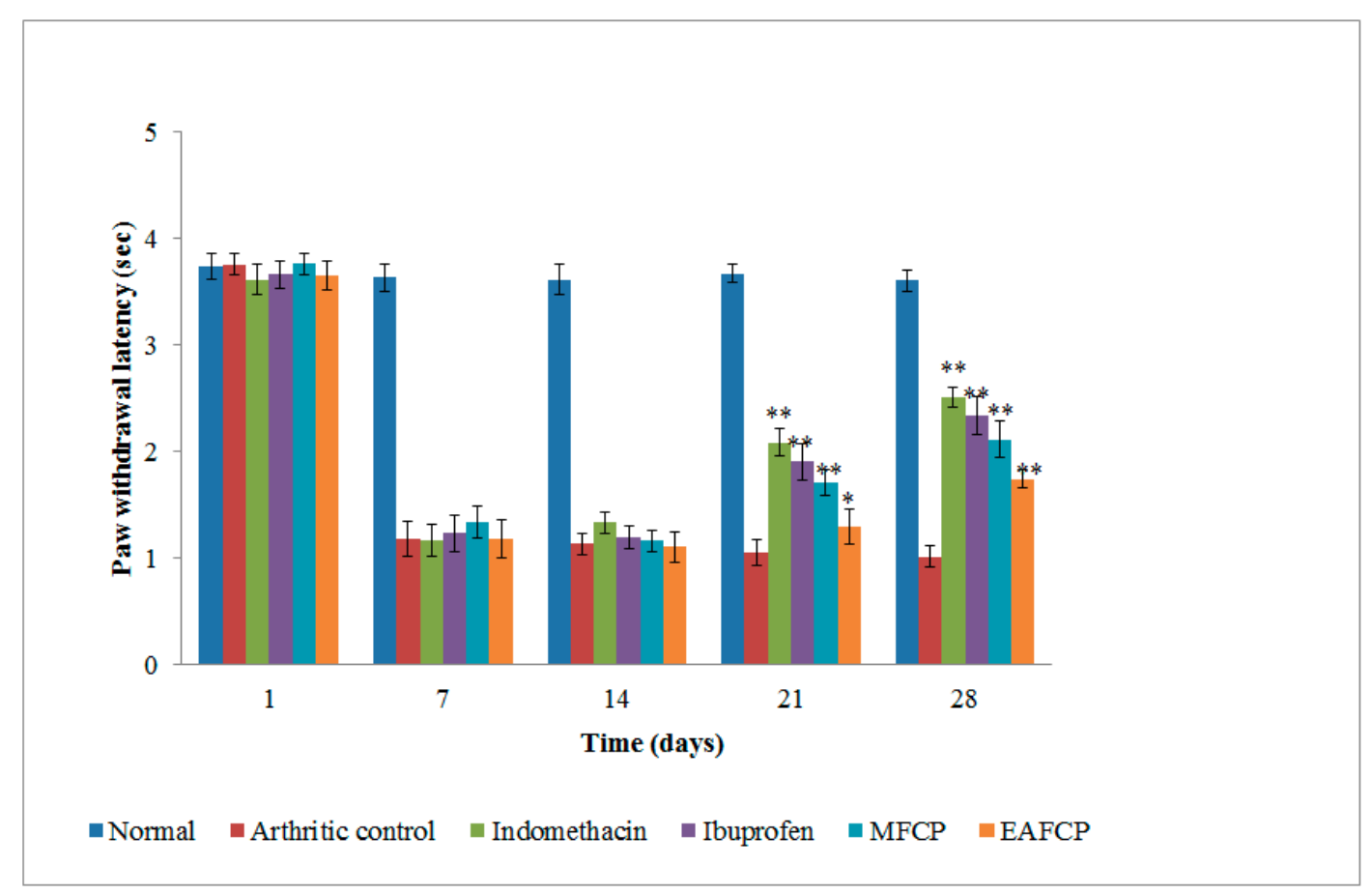

Figure 2. Measurement of paw withdrawal latency. Values are mean \pm SEM for 6 animals; statistical analysis by one-way ANOVA followed by Dunnett test using Graphpad Instat software; ${ }^{*} p<0.05$ and ${ }^{* *} p<0.01$ when compared to arthritic control normal control. 


\subsubsection{Body Weight}

All animals injected with FCA showed the reduction in the body weight which might be due to the decreased absorption of nutrients of Swallow wort through the intestine [45]. However, the treatment with both of the standards (indomethacin and ibuprofen) and plant fractions showed increase in the body weight from the 12th day onwards. The MFCP and EAFCP were found to almost restore the body weight in the progressive manner such as in case of indomethacin and ibuprofen (Figure 3). Overall, both MFCP and EAFCP were found to have a good impact on the body weight of the rats.

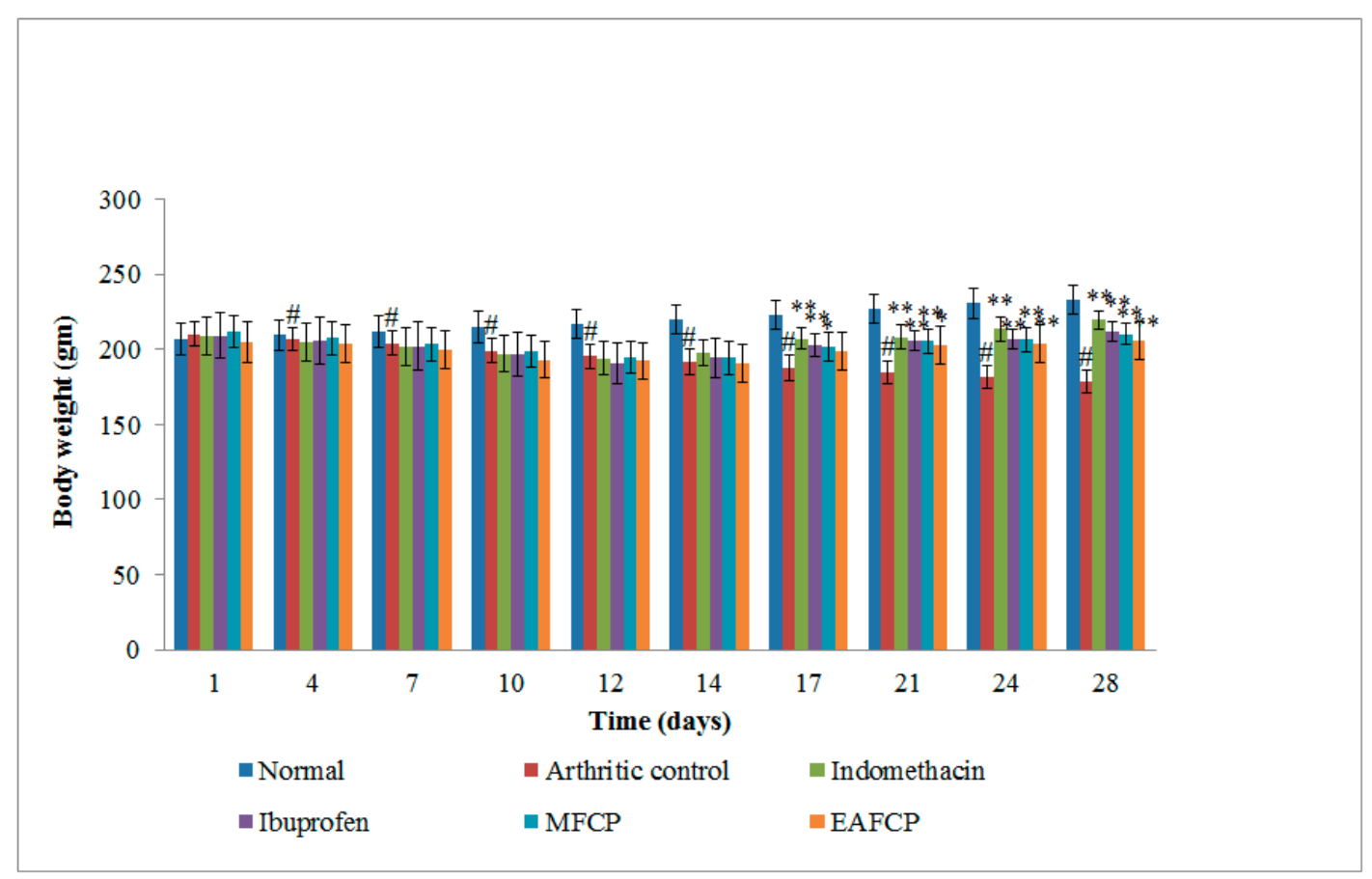

Figure 3. Effect of Swallow wort fractions on body weight. Values are mean \pm SEM for 6 animals; statistical analysis by one-way ANOVA followed by Dunnett test using GraphpadInstat software; ${ }^{*} p<0.05,{ }^{* *} p<0.01$ when compared to arthritic control, and ${ }^{\#} p<0.01$ when compared to normal control.

\subsubsection{Measurement of Spleen and Thymus Weights}

Immunological functions are related to the thymus and spleen indexes. On the 28th day, the rats were sacrificed and thymus index and spleen index were determined. As presented in Table 3, the weights of spleen and thymus for MFCP group animals were found to be significantly lower than arthritic control group $(p<0.01)$. The MFCP also showed greater effect in thymus weight $(0.13 \pm 0.017 \mathrm{~g})$ than ibuprofen $(0.14 \pm 0.017 \mathrm{~g})$ but slightly lower effect in spleen weight $(0.33 \pm 0.014 \mathrm{~g})$ than ibuprofen $(0.37 \pm 0.01 \mathrm{~g})$. The weight of spleen and thymus for EAFCP group animals was also found to be significantly lower than the arthritic control $(p<0.01)$. Based on these observations, MFCP was found to be much better than EAFCP in reducing the thymus and spleen weights. 
Table 3. Measurement of spleen and thymus weights in FCA-induced arthritis.

\begin{tabular}{ccc}
\hline \multirow{2}{*}{ Groups } & \multicolumn{2}{c}{ Organs Weight (g) } \\
\cline { 2 - 3 } & Spleen & Thymus \\
\hline Normal & $0.21 \pm 0.01$ & $0.11 \pm 0.01$ \\
Arthritic control & $0.44 \pm 0.012^{*}$ & $0.2 \pm 0.011^{\#}$ \\
Indomethacin $10 \mathrm{mg} / \mathrm{kg}$ & $0.29 \pm 0.012^{* *}$ & $0.13 \pm 0.016^{* *}$ \\
Ibuprofen15 $\mathrm{mg} / \mathrm{kg}$ & $0.37 \pm 0.01^{* *}$ & $0.14 \pm 0.017^{* *}$ \\
MFCP 300 mg/kg & $0.33 \pm 0.014^{* *}$ & $0.13 \pm 0.017^{* *}$ \\
EAFCP 300 mg/kg & $0.41 \pm 0.024^{* *}$ & $0.18 \pm 0.008^{* *}$ \\
\hline
\end{tabular}

Values are mean \pm SEM for 6 animals. ${ }^{* *} p<0.01$ vs. control group and ${ }^{\#} p<0.01$ when compared to normal control. One-way ANOVA followed by Dunnett test were used.

\subsubsection{Serum Lysosomal Enzymes in FCA-Induced Arthritis}

Enzymes such as AST, ALT, and ALP have significant roles in the formation of biologically active chemical mediators such as bradykinins in the inflammatory process [46]. In addition, serum AST, ALT, and ALP are the specific biomarkers which are useful in the evaluation of liver damage [13]. Therefore, the levels of AST, ALT, and ALP were measured in this study. All group animals treated with FCA caused an increase in the level of these enzymes. However, the treatment of animals with MFCP $(300 \mathrm{mg} / \mathrm{kg})$, EAFCP $(300 \mathrm{mg} / \mathrm{kg})$, indomethacin $(10 \mathrm{mg} / \mathrm{kg})$, and ibuprofen $(15 \mathrm{mg} / \mathrm{kg})$ significantly reduced the elevated levels of serum enzymes (Table 4), while the animals treated with MFCP showed greater effect than EAFCP.

Table 4. Serum lysosomal enzyme in FCA-induced arthritis.

\begin{tabular}{cccc}
\hline \multirow{2}{*}{ Groups } & \multicolumn{3}{c}{ Serum Enzymes on Different Days } \\
\cline { 2 - 4 } & AST (U/mL) & ALT (U/mL) & ALP (U/mL) \\
\hline Normal & $32.33 \pm 0.81$ & $26.16 \pm 0.98$ & $42.83 \pm 1.72$ \\
Arthritic control & $76.66 \pm 1.63^{*}$ & $74 \pm 1.6^{*}$ & $122.66 \pm 1.63^{\#}$ \\
Indomethacin $10 \mathrm{mg} / \mathrm{kg}$ & $38.16 \pm 1.72^{* *}$ & $35.66 \pm 1.3^{* *}$ & $42.33 \pm 1.36^{* *}$ \\
Ibuprofen15 $\mathrm{mg} / \mathrm{kg}$ & $42.33 \pm 1.36^{* *}$ & $38.66 \pm 1.03^{* *}$ & $55.83 \pm 1.16^{* *}$ \\
MFCP 300 $\mathrm{mg} / \mathrm{kg}$ & $45.16 \pm 0.75^{* *}$ & $41.83 \pm 0.75^{* *}$ & $56 \pm 1.78^{* *}$ \\
EAFCP 300 $\mathrm{mg} / \mathrm{kg}$ & $49.66 \pm 1.5^{* *}$ & $47.5 \pm 1.04^{* *}$ & $62.16 \pm 1.47^{* *}$ \\
\hline
\end{tabular}

Values are mean \pm SEM for 6 animals. ${ }^{* *} p<0.01$ vs. control group and ${ }^{\#} p<0.01$ when compared to normal control. One-way ANOVA followed by Dunnett test were used.

\subsubsection{Alterations in CRP and RF in FCA-Induced Arthritis in Rats}

The serum CRP and RF are the markers of the inflammation and antibody production against the injected FCA. The high levels of CRP $(7.1 \mathrm{mg} / \mathrm{L})$ and RF (59.71 IU/L) were recorded in the FCA control group animals. However, the MFCP, EAFCP, indomethacin, and ibuprofen treatments significantly reduced the levels of CRP and RF $(p<0.01)$ as shown in Table 5. The effects of MFCP were better than EAFCP. Hence, MFCP can be effectively utilized in reducing the serum levels of CRP and RF compared to EAFCP.

\subsubsection{TNF- $\alpha$ and IL-6}

Proinflammatory cytokines such as TNF- $\alpha$ and IL-6 play essential roles in the pathogenesis of RA. Therefore, the levels of TNF- $\alpha$ and IL- 6 cytokines in the serum of arthritic rats were analyzed and results are shown in Figure 4 . The levels of TNF- $\alpha$ and IL- 6 were significantly elevated in FCA-induced arthritic rats $(p<0.01)$. However, the treatment of arthritic rats with MFCP reduced the elevated levels of serum TNF- $\alpha$ and IL-6. This effect was almost equivalent to that of standard ibuprofen. The treatment of arthritic rats with EAFCP also reduced the elevated levels of serum TNF- $\alpha$ and IL- 6 compared to arthritic control but its level was significantly higher than MFCP and both of the standards $(p<0.05)$. 
Table 5. Alterations in C-reactive protein (CRP) and rheumatoid factor (RF) in FCA-induced arthritis in rats.

\begin{tabular}{ccc}
\hline Groups & RF (IU/L) & CRP (mg/L) \\
\hline Normal control & - & $1.19 \pm 0.3$ \\
Arthritic control & $59.71 \pm 1.18^{\#}$ & $7.1 \pm 0.48^{\#}$ \\
Indomethacin $(10 \mathrm{mg} / \mathrm{kg})$ & $34.55 \pm 0.96^{* *}$ & $2.41 \pm 0.51^{* *}$ \\
Ibuprofen $(15 \mathrm{mg} / \mathrm{kg})$ & $37.08 \pm 0.91^{* *}$ & $2.93 \pm 0.51^{* *}$ \\
MFCP $300 \mathrm{mg} / \mathrm{kg}$ & $46.03 \pm 1.25^{* *}$ & $4.1 \pm 0.49^{* *}$ \\
EAFCP $300 \mathrm{mg} / \mathrm{kg}$ & $49.34 \pm 1.21^{* *}$ & $6.38 \pm 0.34^{* *}$ \\
\hline
\end{tabular}

Values are mean \pm SEM for 6 animals. ${ }^{* *} p<0.01$ vs. control group and ${ }^{\#} p<0.01$ when compared to normal control. One-way ANOVA followed by Dunnett test were used.

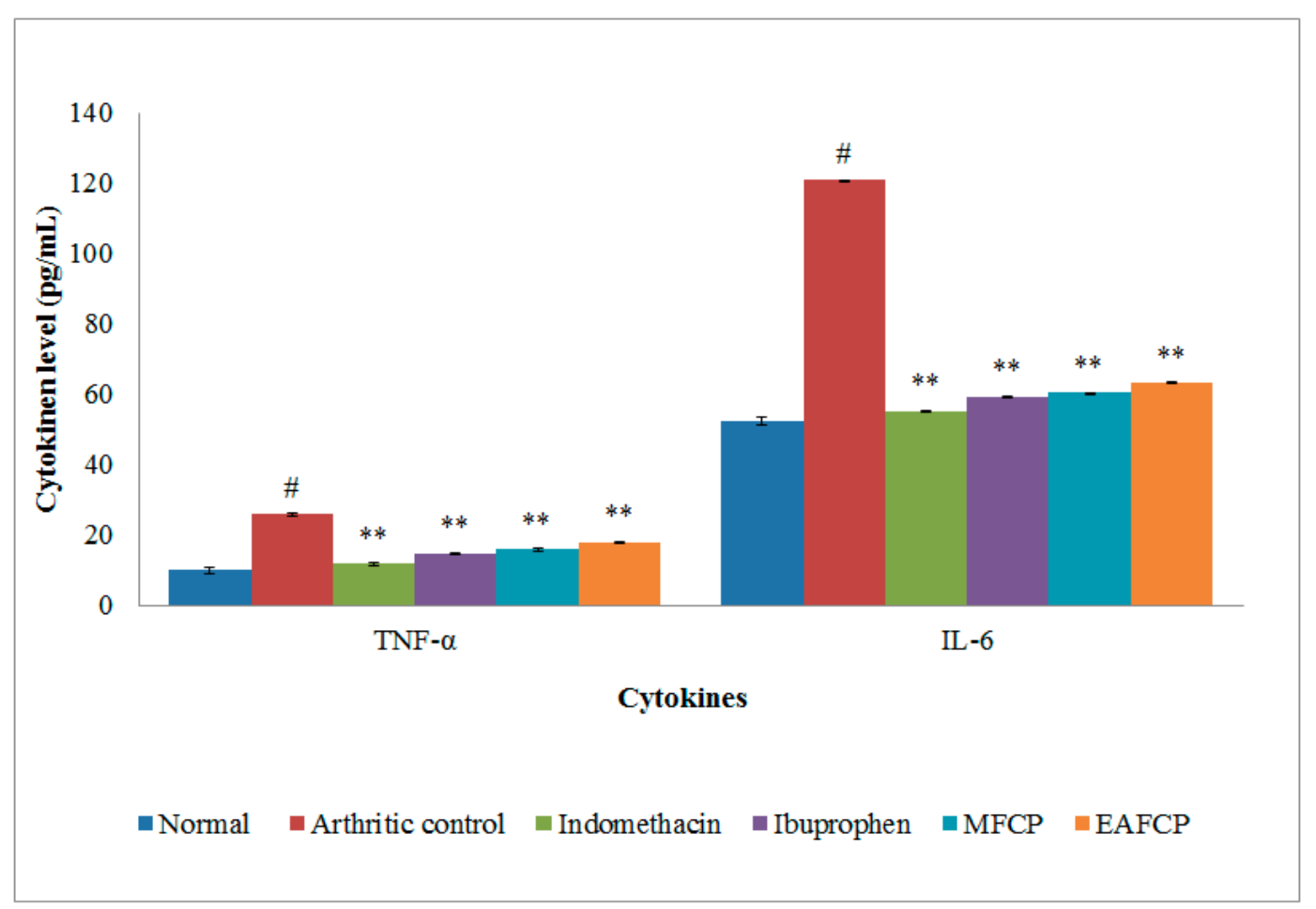

Figure 4. Effects of Swallow wort fractions on cytokine production in serum. Values are mean \pm SEM for 6 animals; statistical analysis by one-way ANOVA followed by Dunnett test using Graphpad Instat software; ${ }^{* *} p<0.01$ when compared to arthritic control and ${ }^{\#} p<0.01$ when compared to normal control.

\subsubsection{Radiological Analysis of Ankle Joints}

Figure 5A presents the photographs of the tarsotibial joint swelling of the left hind paws from different groups on the 14th day after CFA injection. Figure 5B presents the $\mathrm{X}$-ray radiographs of the same paws recorded on the 28th day. The radiographic analysis of the hind legs for FCA-induced arthritic rats presented soft tissue swelling (phalangeal region) along with joint space narrowing (intertarsal joints), cystic enlargement of the bone, and extensive erosions which clearly indicated the degeneration of the cartilage (Figure 5). However, the treatment with MFCP, EAFCP, indomethacin, and ibuprofen reduced the narrowing of joint space and improved the radiographic pattern of the joints. The radiographic patterns of the joints were found to be better in MFCP treated animals than EAFCP threated animals. 

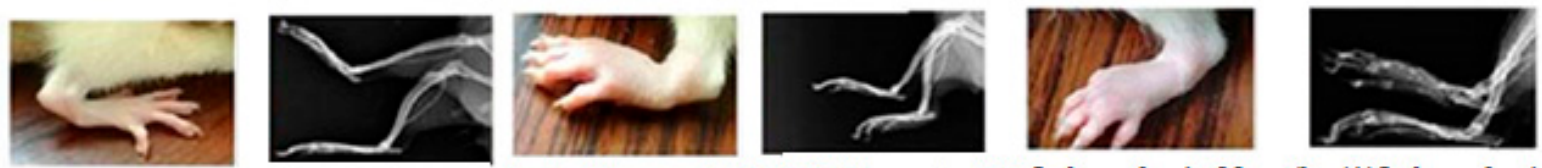

Normal control (A) Normal control (B) Arthritic control (A) Arthritic control (B) Indomethacin $10 \mathrm{mg} / \mathrm{kg}$ (A)Indomethacin $10 \mathrm{mg} / \mathrm{kg}$ (B)
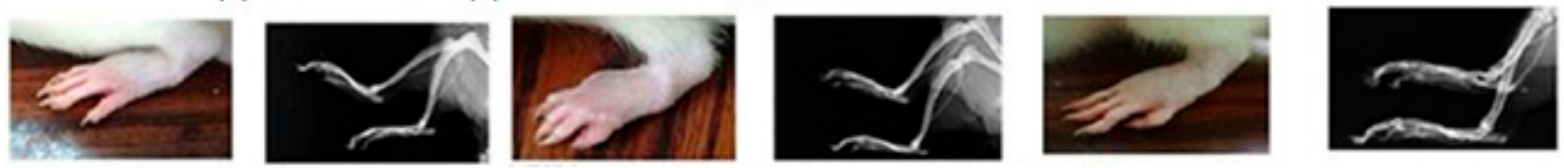

Ibuprofen $15 \mathrm{mg} / \mathrm{kg}$ (A) Ibuprofen $15 \mathrm{mg} / \mathrm{kg}$ (B) MFCP $300 \mathrm{mg} / \mathrm{kg}$ (A)MFCP $300 \mathrm{mg} / \mathrm{kg}$ (B) EAFCP $300 \mathrm{mg} / \mathrm{kg}$ (A) EAFCP $300 \mathrm{mg} / \mathrm{kg}$ (B)

Figure 5. Photographic and radiographic analysis of FCA-induced arthritis in rats. (A) Photographic of the left hind paw taken 14 days after FCA injection and (B) radiographic analysis of the left and right hind paws at day 21 after FCA injection.

\section{Discussion}

Swallow wort is growing wildly as an Ayurvedic plant with important medicinal properties. The leaves, latex, flowers, stems, and roots of Swallow wort are used traditionally to treat complications such as ulcers, leprosy, tumors, inflammatory disorders, piles, and liver diseases [22]. Anti-inflammatory efficacy of the latex of Swallow wort has been demonstrated in various animal models [28]. The warm leaf paste of Swallow wort is usually applied on the swollen part to minimize the inflammation and pain [48]. Although the leaves of this plant are reported to have traditional uses regarding its beneficial effects in inflammatory conditions, these claims are not experimentally verified. In our earlier studies, we found significant activity of Swallow wort (extract and fraction) in in vitro, carrageenan-induced paw edema, and formalin-induced paw edema rat models [49]. The PASS studies were performed to predict the biological activities of various phytoconstituents present in Swallow wort leaves. Based on current phytochemical analysis and reported gas-chromatography mass-spectrometry data of Swallow wort leaves, several reported phytoconstituents of Swallow wort leaves were utilized for the prediction of biological activities [50]. The PASS studies predicted the anti-inflammatory potentials of most of its constituents such as $\alpha$-amyrin, $\beta$-amyrin, stigmasterol, and $\beta$ - sitosterol. These compounds also showed good anti-inflammatory activities in experimental animal models [51,52]. So, in the present study, we have investigated the antiarthritic potential of different fractions of Swallow wort leaves using an FCA-induced arthritis model. Due to unavailability of female rats, these studies were carried out on male rats. In addition, no differences were recorded in the susceptibility to RA between the genders previously in the literature [53]. Hence, either sex of the rats can be selected for these studies.

FCA-induced arthritis model is the most common chronic model which is comparable to the human RA model [54]. This model is predicted as a progressive increase in the volume of the injected paw of rats and used to evaluate the pathogenesis of RA for the screening of different therapeutics [55]. In this model, the primary reaction of edema and soft-tissue thickening at the depot site is caused by the FCA, which has an irritant effect [56]. However, the secondary lesion is associated with the formation of antibodies [57].

An acute toxicity evaluation demonstrated the nontoxic nature of both of the extracts at the dose of $2000 \mathrm{mg} / \mathrm{kg}$. The selected dose of $300 \mathrm{mg} / \mathrm{kg}$ for both of the extracts was much lower than studied dose of acute toxicity evaluation. Accordingly, a dose of $300 \mathrm{mg} / \mathrm{kg}$ was selected in this study. Although FCA was administered on the 1st and the 6th days of the treatment, the signs of inflammation appeared from the $2^{\text {nd }}$ day, which might be due to fluid exudation, neutrophil infiltration, and mast cell activation. It was followed by a slow regression and the joint swellings [29]. Antiarthritic activity of MFCP was greater than EAFCP, equal to standard ibuprofen, and slightly lower than standard indomethacin, which is indicated by the reduction in paw volume of inhibiting the FCA-challenged rats. Indomethacin, a nonselective COX inhibitor, is a more potent anti-inflammatory, analgesic, and antipyretic than aspirin [58]. 
The swelling of joints and the increased arthritic score are the real index for chronic inflammation of FCA-induced arthritic model [40]. MFCP was found to reduce the arthritic score and paw swelling significantly, which was similar to that of standard ibuprofen (Table 2 and Figure 1). These observations suggest the possible immunosuppressant effects of MFCP [54]. The animal groups that underwent MFCA and EAFCP treatments showed a marked enhancement in rat body weight compared to the arthritic control group. A significant reduction in rat body weight was witnessed due to the decreased absorption of nutrients from the intestine in FCA-challenged rats. Similar to that of standards indomethacin and ibuprofen, MFCP significantly restored the body weight of the rats which may be due to the improvement in the arthritic condition, which in turn, may normalize the absorption of nutrients from the intestine. These result also suggested that there is a close relationship between the extent of inflammation and the loss of body weight [59]. These results were in good agreement with those reported for the treatment of monoarthritis in rats using a latex extract of Swallow wort [29].

In adjuvant arthritis, the spleen is an essential organ for the formation of cells and antibodies, which are responsible for the immunological effects. The increase in the cellularity occurs in the spleen of the arthritic rats [10]. The organ weight of the spleen and thymus in FCA-induced rats was evidently increased in the present study [60]. The MFCP and EAFCP resulted in the increased weight of the spleen and thymus, probably by suppression of splenic lymphocytes and inhibition of the infiltration lymphocytes into the synovium [11].

Additional verifications of the antiarthritic potentials of MFCP, EAFCP, indomethacin, and ibuprofen were assessed by the estimation of the various biochemical parameters of rat serum including AST, ALT, ALP, CRP, and RF, which are important tools to study the antiarthritic potential of the drugs. In the inflammatory process, AST and ALT are responsible for the formation of inflammatory mediators such as bradykinins [61]. In the FCA model, the liver function indicative enzymes may be altered due to the enhancement in liver and bone fractions. This is associated with localized bone erosion and periarticular osteopenia. The CRP levels increased during inflammation which might be due to the rise in the IL-6 levels. This is produced by the macrophages and the adipocytes [62]. FCA-induced arthritis is linked with an increase in the RF and CRP levels [54]. In this study, the treatment of arthritic rats with MFCP, EAFCP, indomethacin, and ibuprofen significantly reduced the elevated levels of AST, ALT, ALP, CRP, and RF in rat serum. The animals treated with MFCP showed a greater effect than EAFCP. These studies suggested the potential of studied fractions of Swallow wort in the treatment of RA. The significant reduction in the elevated serum levels of AST, ALT, and ALP also suggested that the studied fractions did not cause hepatic injury to the rats [13]. Overall, the results of lysosomal enzyme measurements were found to be in good agreement with those reported previously in the literature for the Solanum xanthocarpum fruit extract [13].

Cytokines are the mediators of inflammatory conditions. The synovial macrophages and fibroblasts produce an excess amount of ILs, TNF- $\alpha$, and other cytokines. Moreover, the activated neutrophils are also the sources of leukotrienes and prostaglandins. Mediators such as IL, IL- $1 \beta$, IL- 6 , and TNF- $\alpha$ are responsible for the pathogenesis and progression of RA [40]. In the present study, the serum TNF- $\alpha$ and IL-6 levels were significantly increased in FCA-induced arthritic rats. However, the treatment with MFCP showed the maximum inhibition of TNF- $\alpha$ and IL-6 levels compared to EAFCP. These results were in accordance with those reported for latex extraction of Swallow wort [29].

For the diagnosis of tissue swelling, erosions, and joint deformity in arthritis patients, radiographic images are used. This gives an idea about soft tissue lesions which are observed as an early sign of the arthritis. The bone erosion and deterioration in trabecular bone are also typical pathologic changes of human arthritis [63]. In FCA-induced arthritic rats, soft tissue swelling along with a narrowing of the joint spaces was recorded, which implies bone destruction in arthritic conditions. The radiographic observations of the 
treatments group with MFCP and EAFCP inhibited the arthritis-associated joint changes (Figure 4).

The antiarthritic effects of MFCP and EAFCP could be due to the presence of different classes of phytochemicals including flavonoids, alkaloids, terpenoids, glycosides, saponins, tannins, and steroids, which were identified using preliminary phytochemical screening. Accordingly, the current investigation showed that the leaf of Swallow wort markedly reduced the paw inflammation, serum enzyme levels, and release of proinflammatory mediators associated with RA and hence it has great potential in the treatment of RA.

\section{Conclusions}

The results of the current investigation contribute toward the exploration of Swallow wort leaf extracts in the treatment of RA. The obtained data suggested that the antiarthritic potentials of MFCP and EAFCP might be due to the protection of vascular permeability, synovial membrane, and prevention of cartilage destruction, which could finally result in improved health status. It also demonstrates its beneficial effects during recovery from RA by including body weight, arthritic score, and organ weights along with clinical signs including paw edema, paw withdrawal latency, and radiological pattern. This research established the antiarthritic potential of MFCP in Wistar rats. However, further investigations are required to identify and isolate the potential phytoconstituents responsible for the antiarthritic efficacy, which could facilitate the utilization of Swallow wort in arthritic disorders.

Author Contributions: Conceptualization, S.C.D. and M.F.; methodology, V.S.S., F.S., S.A. and M.F.; software, V.S.S.; validation, S.C.D., S.A. and F.S.; formal analysis, V.S.S. and F.S.; investigation, M.F.; resources, S.C.D.; data curation, F.S.; writing —original draft preparation, V.S.S.; writing—review and editing, S.C.D., F.S., M.F. and S.A.; visualization, V.S.S.; supervision, S.C.D.; project administration, S.C.D.; funding acquisition, S.A. All authors have read and agreed to the published version of the manuscript.

Funding: This research was funded by the Researchers Supporting Project (number RSP-2020/146) at King Saud University, Riyadh, Saudi Arabia and the APC was also funded by the Researchers Supporting Project.

Institutional Review Board Statement: The study was conducted according to the guidelines of the Declarations of Helsinki, and approved by the Institutional Animal Ethics Committee (Reg. No. 731/PO/Re/2002/CPCSEA), Approval No. CPCSEA/CBPL/AH-11 under the Committee for "Purpose of Control and Supervision of Experiments on Animals (CPCSEA)".

Informed Consent Statement: Not applicable.

Data Availability Statement: Not applicable.

Acknowledgments: The authors are thankful to the Researchers Supporting Project (number RSP2020/146) at King Saud University, Riyadh, Saudi Arabia for funding this project. The authors are also thankful to S.R.T. University for providing facilities to carry out these studies.

Conflicts of Interest: The authors declare no conflict of interest associated with this manuscript.

\section{References}

1. Putterman, C. Introduction: New treatment paradigms in rheumatoid arthritis. Am. J. Orthopaed. 2006, 36, S2-S3.

2. Tanaka, T. Introduction for inflammation and cancer. Sem. Immunopathol. 2013, 35, 121-122. [CrossRef] [PubMed]

3. Bihania, G.V.; Rojatkar, S.R.; Bodhankar, S.L. Anti-arthritic activity of methanol extract of Cyathocline purpurea (whole plant) in Freund's complete adjuvant-induced arthritis in rats. Biomed. Aging Pathol. 2014, 4, 197-206. [CrossRef]

4. Reddy, D.; Trost, L.W.; Lee, T.; Baluch, A.R.; Kaye, A.D. Rheumatoid arthritis: Current pharmacologic treatment and anesthetic considerations. Middle East J. Anesthesiol. 2007, 19, 311-335.

5. McInnes, I.B.; Schett, G. The pathogenesis of rheumatoid arthritis. N. Eng. J. Med. 2011, 365, 2205-2219. [CrossRef]

6. Bhardwaj, L.K.; Chandrul, K.K.; Sharma, U.S. Evaluation of anti-arthritic activity of Ficus benghalensis Linn. root extracts on Freund's adjuvant induced arthritis. J. Phytopharmacol. 2006, 5, 10-14.

7. Fan, A.; Lao, L.; Zhang, R.; Zhou, A.; Wang, L.; Moudgil, K. Effects of an acetone extract of Boswellia carterii Birdw (Burseraceae) gum resin on adjuvant-induced arthritis in lewis rats. J. Ethnopharmacol. 2005, 101, 104-109. [CrossRef] 
8. Ofman, J.J.; Badamgarav, E.; Henning, J.M.; Knight, K.; Laine, L. Utilization of nonsteroidal anti-inflammatory drugs and anti secretory agents: A managed care claims analysis. Am. J. Med. 2004, 116, 835-842. [CrossRef]

9. American college of rheumatology ad hoc Committee on clinical guidelines. Guidelines for the management of rheumatoid arthritis. Arth. Rheum. 1996, 39, 713-722. [CrossRef]

10. Choudhary, M.; Kumar, V.; Gupta, P.; Singh, S. Investigation of antiarthritic potential of Plumeria alba L. leaves in acute and chronic models of arthritis. BioMed. Res. Int. 2014, 2014, 474616. [CrossRef]

11. Choudhary, M.; Kumar, V.; Gupta, P.K.; Singh, S. Anti-arthritic activity of Barleria prionitis Linn. leaves in acute and chronic models in Sprague Dawley rats. Bull. Facul. Pharm. Cairo Univ. 2014, 52, 199-209. [CrossRef]

12. Vedpal; Gupta, S.K.; Gupta, A.K.; Pakash, D.; Gupta, A. Anti-arthritic activity of Desmodium gangeticum root. Int. Res. J. Pharm. 2013, 4, 100-102.

13. Gupta, R.K.; Hussain, T.; Panigrahi, G.; Das, A.; Singh, G.N.; Sweety, K.; Faiyazuddin, M.; Rao, C.V. Hepatoprotective effect of Solanum xanthocarpum fruit extract against CCl4 induced acute liver toxicity in experimental animals. Asian Pac. J. Trop. Med. 2011, 4, 964-968. [CrossRef]

14. Perera, H.D.S.M.; Samarasekera, J.K.R.R.; Handunnetti, S.M.; Weerasena, O.V.D.S.J. In vitro anti-inflammatory and anti-oxidant activities of Sri Lankan medicinal plants. Ind. Crops Prod. 2016, 94, 610-620. [CrossRef]

15. Mahboubi, M. Elaeagnus angustifolia and its therapeutic applications in osteoarthritis. Ind. Crops Prod. 2018, 121, 36-45. [CrossRef]

16. Ali, B.; Mujeeb, M.; Aeri, V.; Mir, S.R.; Faiyazuddin, M.; Shakeel, F. Anti-inflammatory and antioxidant activity of Ficus carica Linn. leaves. Nat. Prod. Res. 2012, 26, 460-465. [CrossRef]

17. Azhar, M.F.; Siddiqui, M.T.; Ishaque, M.; Tanveer, A. Study of ethnobotany and indegenous use of Calotropis procera (Ait.) in Cholistan desert, Punjab, Pakistan. J. Agric. Res. 2014, 52, 117-126.

18. Meena, A.K.; Yadav, A.; Rao, M.M. Ayurvedic uses and pharmacological activities of Calotropis procera Linn. Asian J. Trad. Med. 2011, 6, 45-53.

19. Panda, P.; Das, B.; Sahu, D.S.; Meher, S.K.; Das, B.K.; Rao, M.M.; Lakshmi, G.C.H.D.N. Important uses of arka (Calotropis procera Linn) in Indian system of medicine with pharmacological evidence. Res. J. Pharmacol. Pharmacodyn. 2015, 7, 46-49. [CrossRef]

20. Biswasroy, P.; Panda, S.; Das, D.; Kar, D.M.; Ghosh, D. Pharmacological investigation of Calotropis gigantea: A benevolent herb of nature. Res. J. Pharm. Technol. 2020, 13, 461-467. [CrossRef]

21. Ramachandran Setty, S.; Quereshi, A.A.; Viswanath Swamy, A.H.; Patil, T.; Prakash, T.; Prabhu, K.; Veeran Gouda, A. Hepatoprotective activity of Calatropis procera flowers against paracetamol-induced hepatic injury in rats. Fitoterapia 2007, 78, 451-454. [CrossRef] [PubMed]

22. Moustafa, A.M.; Ahmed, S.H.; Nabil, Z.I.; Hussein, A.A.; Omran, M.A. Extraction and phytochemical investigation of Calotropis procera: Effect of plant extracts on the activity of diverse muscles. Pharm. Biol. 2010, 48, 1080-1190. [CrossRef] [PubMed]

23. Nenaah, G.E. Potential of using flavonoids, latex and extracts from Calotropis procera (Ait.) as grain protectants against two coleopteran pests of stored rice. Ind. Crops Prod. 2013, 45, 327-334. [CrossRef]

24. Kumar, V.L.; Basu, N. Anti-inflammatory activity of the latex Calotropis procera. J. Ethnopharmacol. 1994, 44, 123-125. [CrossRef]

25. Iqbal, Z.; Lateef, M.; Jabbar, A.; Muhammad, G.; Khan, M.N. Anthelmintic activity of Calotropis procera (Ait.) Ait. F. flowers in sheep. J. Ethanopharmacol. 2005, 102, 256-261. [CrossRef] [PubMed]

26. Kamath, J.V.; Rana, A.C. Pharmacological activities of ethanolic extract of Calotropis procera roots. Indian Drugs 2003, 40, $292-295$.

27. Kareem, S.O.; Akpan, I.; Ojo, O.P. Antimicrobial activities of Calotropis procera on selected pathogenic microorganisms. Afr. J. Biomed. Res. 2008, 11, 105-110. [CrossRef]

28. Butler, S.H.; Godefroy, F.; Besson, J.M.; Weil-Fugazza, J. A limited arthritic model for chronic pain studies in the rat. Pain 1992, 48, 73-78. [CrossRef]

29. Kumar, V.L.; Roy, S. Calotropis procera Latex extract affords protection against inflammation and oxidative stress in Freund's complete adjuvant-induced monoarthritis in rats. Med. Inflamm. 2007, 2007, 47523. [CrossRef]

30. Kumar, V.L.; Roy, S. Protective effect of latex of Calotropis procera in Freund's complete adjuvant induced monoarthritis. Phytother. Res. 2009, 23, 1-5. [CrossRef]

31. Sangraula, H.; Dewan, S.; Kumar, V.L. Evaluation of anti-inflammatory activity of latex of Calotropis procera in different models of inflammation. Inflammopharmacology 2002, 9, 257-264. [CrossRef]

32. Kumar, V.L.; Chaudhary, P.; Ramos, M.V.; Moahn, M.; Matos, M.P.V. Protective effects of proteins derived latex of Calotropis procera against inflammatory hyperalgesia in monoarthritic rats. Phytother. Res. 2011, 25, 1336-1341. [CrossRef] [PubMed]

33. Chaudhary, P.; Ramos, M.V.; Vasconcelos, M.D.S.; Kumar, V.L. Protective effects of high molecular weight protein sub-fraction of Calotropis procera latex in monoarthritic rats. Pharmacog. Mag. 2016, 112, S147-S151.

34. Chandrasekar, R.; Chandrasekar, S. Natural herbal treatment for rheumatoid arthritis-a review. Int. J. Pharm. Sci. Res. 2017, 8, 368-384.

35. Khandelwal, K.R. Practical Pharmacognosy; Nirali Prakashan: Pune, India, 2004; pp. 149-155.

36. Parasuraman, S. Computer-aided prediction of biological activity spectra, pharmacological and toxicological properties of cleistanthin A and B. Int. J. Res. Pharm. Sci. 2010, 1, 333-337.

37. Filimonov, D.A.; Lagunin, A.A.; Gloriozova, T.A.; Rudik, A.V.; Druzhilovskii, D.S.; Pogodin, P.V.; Poroikov, V.V. Prediction of the biological activity spectra of organic compounds using the pass online web resource. Chem. Het. Comp. 2014, 50, 444-457. [CrossRef] 
38. Jamkhande, P.G.; Barde, S.R. Evaluation of anthelmintic activity and in silico PASS assisted prediction of Cordia dichotoma (Forst.) root extract. Anc. Sci. Life 2014, 34, 39-43. [CrossRef]

39. Sambavekar, P.P.; Aitawade, M.M.; Patil, D.R.; Kolekar, G.B.; Deshmukh, M.B.; Anbhule, P.V. In-silico, in-vitro antibacterial activity and toxicity profile of new quinoline derivatives. Indian J. Chem. 2013, 52, 1521-1526.

40. Thite, A.T.; Patil, R.R.; Naik, S.R. Anti-arthritic activity profile of methanolic extract of Ficus bengalensis: Comparison with some clinically effective drugs. Biomed. Aging Pathol. 2014, 4, 207-217. [CrossRef]

41. Kshirsagar, A.D.; Panchal, P.V.; Harle, U.N.; Nanda, R.K.; Shaikh, H.M. Anti-Inflammatory and antiarthritic activity of anthraquinone derivatives in rodents. Int. J. Inflamm. 2014, 2014, 690596. [CrossRef]

42. Mali, S.M.; Sinnathambi, A.; Kapase, C.U.; Bodhankar, S.L.; Mahadik, K.R. Anti-arthritic activity of standardised extract of Phyllanthus amarus in Freund's complete adjuvant induced arthritis. Biomed. Aging Pathol. 2011, 1, 185-190. [CrossRef]

43. Arya, S.; Kumar, V.L. Anti-inflammatory efficacy of extracts of latex of Calotropis procera against different mediators of inflammation. Med. Inflamm. 2005, 4, 228-232. [CrossRef] [PubMed]

44. Kumar, V.L.; Roy, S.; Sehgal, R.; Padhy, B.M. A comparative study on the efficacy of rofecoxib in monoarticular arthritis induced by latex of calotropis procera and freund's complete adjuvant. Inflammopharmacology 2006, 14, 17-21. [CrossRef] [PubMed]

45. Zhang, G.Q.; Huang, X.D.; Wang, H.; Leung, A.K.; Chan, C.L.; Fong, D.W.; Yu, Z.L. Anti-inflammatory and analgesic effects of the ethanol extract of Rosa multiflora Thunb. hips. J. Ethnopharmacol. 2008, 118, 290-294. [CrossRef]

46. Asquith, D.L.; Miller, A.M.; McInnes, I.B.; Liew, F.Y. Animal models of rheumatoid arthritis. Eur. J. Immunol. 2009, 39, $2040-2044$. [CrossRef]

47. Mythilypriya, R.; Shanthi, P.; Sachdanandam, P. Salubrious effect of Kalpaamruthaa, a modified indigenous preparation in adjuvant-induced arthritis in rats-a biochemical approach. Chem. Biol. Inter. 2008, 173, 148-158. [CrossRef]

48. Pawar, S.; Patil, D.A. Folk remedies against rheumatic disorders in Jalgaon district, Maharashtra. Indian J. Trad. Know. 2006, 5, 314-316.

49. Singh, V.S.; Dhawale, S.C.; Shakeel, F.; Faiyazuddin, M.; Alshehri, S. In vitro and in vivo anti-inflammatory effects of Calotropis procera leave fractions. unpublished work, manuscript in preparation.

50. Sameeh, M.Y.; Mohamed, A.A. Characterization of polyphenols, their antioxidant and GC-MS analysis of wild Calotropis procera leaves and fruit extracts. Int. J. Chem. Tech. Res. 2018, 11, 319-327.

51. Wu, C.R.; Hseu, Y.C.; Lien, J.C.; Lin, L.W.; Lin, Y.T.; Ching, H. Triterpenoid contents and anti-inflammatory properties of the methanol extracts of Ligustrum species leaves. Molecules 2011, 16, 1-15. [CrossRef]

52. Mallick, S.S.; Dighe, V.V. Detection and estimation of alpha-amyrin, beta-sitosterol, lupeol, and n-triacontane in two medicinal plants by high performance thin layer chromatography. Adv. Chem. 2014, 2014, 143948. [CrossRef]

53. Tuncel, J.; Haag, S.; Hoffmann, M.H.; Yau, A.C.Y.; Hulqvist, M.; Olofsson, P.; Backlund, J.; Nandakumar, K.S.; Weidner, D.; Fischer, A.; et al. Animal models of rheumatoid arthritis (I): Pristine-induced arthritis in the rat. PLoS ONE 2016, 11, e0155936. [CrossRef] [PubMed]

54. Patil, K.R.; Patil, C.R.; Jadhav, R.B.; Mahajan, V.K.; Raosaheb, P.; Gaikwad, P.S. Anti-arthritic activity of bartogenic acid isolated from fruits of Barringtonia racemosa Roxb. (Lecythidaceae). Evid.-Based Complement. Altern. Med. 2011, 2011, 785245. [CrossRef] [PubMed]

55. Petchi, R.R.; Parasuraman, S.; Vijaya, C.; Gopala Krishna, S.V.; Kumar, M.K. Antiarthritic activity of a polyherbal formulation against Freund's complete adjuvant induced arthritis in female Wistar rats. J. Basic Clin. Pharmacol. 2015, 6, 77-83. [CrossRef] [PubMed]

56. Jalalpure, S.S.; Mandavkar, Y.D.; Khalure, P.R.; Shinde, G.S.; Shelar, P.A.; Shah, A.S. Antiarthritic activity of various extracts of Mesua ferrea Linn. Seed. J. Ethnopharmacol. 2011, 138, 700-704. [CrossRef] [PubMed]

57. Kubo, M.; Matsuda, H.; Tanaka, M.; Kimura, Y.; Okuda, H.; Higashino, M.; Tani, T.; Namba, K.; Aaichi, S. Studies on scutellariaradix.VII. anti-arthritic and anti-inflammatory action of methanolic extract and flavonoid components from scutellariae radix. Chem. Pharm. Bull. 1984, 32, 2724-2729. [CrossRef] [PubMed]

58. Prasad, P.J. Conceptual Pharmacology; Universities Press: Hydrabad, India, 2010; pp. 254-268.

59. Ekambaram, S.; Perumal, S.S.; Subramanian, V. Evaluation of anti-arthritic activity of Strychnos potatorum Linn seeds in Freund's adjuvant induced arthritic rat model. BMC Complement. Altern. Med. 2010, 10, 56. [CrossRef]

60. Zhang, X.; Dong, Y.; Li, F. Inevestigation of the effect of phlomisoside F on complete Freund's adjuvant-inducced arthritis. Exp. Ther. Med. 2017, 12, 710-718. [CrossRef]

61. Mbiantcha, M.; Almas, J.; Shabana, S.U.; Nida, D.; Aisha, F. Anti-arthritic property of crude extracts of Piptadeniastrum africanum (Mimosaceae) in complete Freund's adjuvant-induced arthritis in rats. BMC Complment. Altern. Med. 2017, 17, E111. [CrossRef]

62. Perumal, S.S.; Ekambaram, P.S.; Dhanam, T. In vivo antiarthritic activity of the ethanol extracts of stem bark and seeds of Calophyllum inophyllum in Freund's complete adjuvant induced arthritis. Pharm. Biol. 2017, 55, 1330-1336. [CrossRef]

63. Almarestani, L.; Fitzcharles, M.A.; Bennett, G.J.; Ribeiro-da-Silva, A. Imaging studies in Freund's complete adjuvant model of regional polyarthritis, a model suitable for the study of pain mechanisms, in the rat. Arth. Rheum. 2011, 63, 1573-1581. [CrossRef] [PubMed] 